Vol.04, No.02, Oktober 2018

Doi: $10.24198 /$ cosmogov.v2i2.xxxxx

\title{
ANALISIS AKUNTABILITAS BELANJA PEMBANGUNAN ANGGARAN PENDAPATAN DAN BELANJA DAERAH PROVINSI JAWA TIMUR SEBELUM DAN SETELAH PEMILIHAN KEPALA DAERAH LANGSUNG
}

\author{
Adinda Laksmi Indara \\ Program Studi Ilmu Politik dan Pemerintahan \\ Fakultas Ilmu Sosial dan Ilmu Politik Universitas Brawijaya \\ Email: adindalaksmi@gmail.com
}

\begin{abstract}
ABSTRAKSI
Selama periode tahun anggaran 2003-2013, ditemukan masih banyak alokasi dana yang harus terus diperbaiki mengingat penerapan pilkada langsung membawa harapan besar akan hasil kepemimpinan yang lebih baik dari sebelumnya. Keberhasilan pelaksanaan otonomi daerah adalah dapat diukur dari tingkat akuntabilitas anggaran di daerah tersebut. Penelitian ini juga menemukan bahwa pilkada langsung tidak membawa dampak signifikan pada efektifitas anggaran di Jawa Timur. Dampak yang dihasilkan nyatanya menunjukkan hasil yang lebih baik pada periode pemerintahan Imam Utomo. Hal ini disebabkan oleh tingkat penyerapan yang kurang, terutama pada beberapa daerah yang akses lokasinya masih susah dijangkau. Faktor lainnya disebabkan oleh adanya ganjalan peraturan dari pusat yang cenderung mengikat daerah dalam mengelola keuangan daerah sesuai yang dibutuhkan oleh publik.
\end{abstract}

Kata kunci: akuntabilitas; anggaran pemerintah; pemilihan umum langsung

\begin{abstract}
Over years of the regional budget of 2003-2013, there is still a lot of the allocation of funds that must be is continuously improved, depends on the remembrance of the application of the local election to bring a hope and results of better leadership than before. Level of success of the implementation of regional autonomy is to be able to measured in terms of the level of woman-budget accountability. This research also found that the local election not having a significant effect on the effectiveness budget. The impact of that turns out to be shows the results of fare particularly better on Imam Utomo's reign. This is caused by less of level absorption of budgeting, especially on some regions which access the locations are difficult to reach. Another factor caused by the fact that both lumped rules designed to weed out from the center of the purposes that tended to be bind of the regions to handle finances by own self, because the region still need mount of money depends on society needs.
\end{abstract}

Keywords: accountability, government budgeting, direct elections. 
Vol.04, No.02, Oktober 2018

Doi: $10.24198 /$ cosmogov.v2i2.xxxxx

\section{PENDAHULUAN}

Berakhirnya masa orde baru mengawali Indonesia memasuki babak baru, yaitu era reformasi. Pemencaran kekuasaan yang melingkupi proses pilkada memang merupakan indikator transisi demokrasi lokal. Tetapi, implementasi pilkada selama era reformasi juga menimbulkan sejumlah masalah. Sebelumnya, partisipasi masyarakat masih belum terjadi dalam proses pilkada di era reformasi. Kekecewaan masyarakat terhadap partai politik, DPRD, dan proses pilkada yang pada akhirnya melahirkan keputusan politik untuk mengubah Undang-undang Nomor 22 Tahun 1999. Perubahan Undangundang Nomor 22 Tahun 1999 menjadi Undang-undang Nomor 32 Tahun 2004 yang ditetapkan pada 15 Oktober 2004 menjadi jawaban bahwa Undang-undang Nomor 22 Tahun 1999 tidak berlaku lagi. Perubahan yang paling mendasar dari produk hukum ini adalah diterapkannya pemilihan langsung oleh rakyat dalam memilih pemimpin daerah. Perubahan pola hubungan Kepala Daerah, DPRD dan masyarakat juga berpengaruh terhadap wilayah akuntabilitas publik di daerah. Asumsinya, semakin besar tingkat akuntabilitas pemerintahan

${ }^{1}$ Dede dan Caroline, Pemilihan Kepala Daerah Secara Langsung: Melahirkan Pemerintahan yang Demokratis? lihat daerah maka semakin tinggi pula tingkat demokratisasi pada level lokal. Persoalan demokratisasi dan desentralisasi politik pada tingkat lokal merupakan kunci utama dalam proses akuntabilitas pemerintahan daerah. Dengan demikian, akuntabilitas publik jelas merupakan bagian dari instrumen masyarakat daerah untuk berdaulat sebagaimana cita-cita otonomi daerah itu sendiri. Tujuan pokok akuntabilitas publik dalam konteks otonomi daerah pada hakikatnya adalah menciptakan suatu kondisi di mana kebijakan yang diambil oleh pemerintah daerah dan DPRD sesuai dengan aspirasi masyarakat. Atau dengan kata lain, sejauhmana pelaksanaan UU dapat membawa perubahan-perubahan kepada kehidupan pemerintahan daerah yang mengutamakan kepentingan rakyat, dalam upaya mendekatkan pemerintah dengan rakyatnya dan dalam rangka meningkatkan kesejahteraan rakyat secara keseluruhan. ${ }^{1}$

\section{Tabel 1}

http://www.academia.edu/1546303/Pemiliha n_Kepala_Daerah_Secara_Langsung_Mela hirkan_Pemerintahan_Daerah_Yang_Demo kratis 
Vol.04, No.02, Oktober 2018

Doi: $10.24198 /$ cosmogov.v2i2.xxxxx

Perbandingan Persentase

Pencapaian Provinsi Jawa Timur

Era Kepemimpinan Imam-

Soenaryo dan Soekarwo-

\begin{tabular}{|l|l|l|}
\multicolumn{2}{|c}{ Syaifullah } \\
\hline & \multicolumn{2}{|c|}{ Prosentase Kenaikan } \\
\hline & Imam - Soenaryo & $\begin{array}{l}\text { Soekarwo - } \\
\text { Syaifullah }\end{array}$ \\
\hline $\begin{array}{l}\text { PDRB Per Kapita Atas } \\
\text { Dasar Harga Berlaku }\end{array}$ & $\mathbf{7 . 3 6}$ & $\mathbf{1 1 . 2 1}$ \\
\hline $\begin{array}{l}\text { Indeks Pembangunan } \\
\text { Manusia }\end{array}$ & $\mathbf{3 . 5 3}$ & $\mathbf{2 . 4 8}$ \\
\hline Angka Harapan Hidup & $\mathbf{1 . 9 0}$ & $\mathbf{1 . 0 2}$ \\
\hline Angka Melek Huruf & $\mathbf{2 . 8 9}$ & $\mathbf{2 . 6 9}$ \\
\hline Rata-Rata Lama Sekolah & $\mathbf{0 . 4 0}$ & $\mathbf{0 . 3 3}$ \\
\hline Angka Kemiskinan & $\mathbf{4 . 4 1}$ & 2.18 \\
\hline $\begin{array}{l}\text { Tingkat Partisipasi } \\
\text { Angkatan Kerja (TPAK) }\end{array}$ & $\mathbf{0 . 7 2}$ & $\mathbf{0 . 5 3}$ \\
\hline $\begin{array}{l}\text { Rata-Rata Lama Sekolah } \\
\text { Laki-Laki }\end{array}$ & $\mathbf{0 . 3 0}$ & $\mathbf{0 . 2 3}$ \\
\hline $\begin{array}{l}\text { Rata-Rata Lama Sekolah } \\
\text { Perempuan }\end{array}$ & $\mathbf{0 . 5 1}$ & $\mathbf{0 . 4 0}$ \\
\hline
\end{tabular}

Sumber: bps.go.id. Diakses tanggal 9 Agustus 2016 (data diolah)

Begitu juga pada bidang kesehatan, Angka Harapan Hidup (AHH) periode 2008-2013 ini masih saja tidak meningkat secara signifikan dibandingkan masa pemerintah tahun 2003-2008. Angka Harapan Hidup (AHH) pada tahun 2008 sebesar $68,7 \%$ dan tahun 2003 sebesar $66,80 \%$, bisa dikatakan meningkat sebesar 1,89\%. Sedangkan AHH 2009 sebesar 69,15 dan 70,09\% pada tahun 2012 yang hanya mengalami kenaikan sebesar $0,94 \%$ saja. Artinya, meskipun LKPJ Gubernur Jawa

${ }^{2}$ Catatan Kinerja Jawa Timur Tahun 20092013 lihat http://prakarsajatim.com/catatan-kinerja-pemerintahprovinsi-jawa-timur-2009-2013/
Timur pada tahun 2009-2012 diklaim meningkat pada kurun waktu 4 tahun terakhir, namun jika ditilik kapasitas fiskalnya, tentu masih jauh lebih memadai era pemerintahan sebelumnya.

Ditilik pada angka kemiskinan, memang sejak tahun 2009 statistiknya mengalami penurunan. Pada tahun 2011 sebesar $14,23 \%$ dan turun menjadi $1,15 \%$ pada tahun 2012, hingga 12,55\% pada tahun 2013. Sayangnya, prosentase tersebut masih tergolong rendah apabila dibandingkan dengan pemerintahan sebelumnya. Dimana tahun 20052006 angka kemiskinan memang mencapai 21,09\% namun berhasil diturunkan hingga $16,68 \%$ atau turun $4,41 \%{ }^{2}$

Setiap tahunnya, banyak daerah mengalami defisit anggaran yang berarti alokasi belanja jauh lebih besar daripada pendapatan daerah. Padahal, pendapatan daerah ini juga masih dibantu oleh Dana Perimbangan. Dana perimbangan ini dimanfaatkan oleh daerah untuk disalurkan kepada masyarakat miskin melalui program-program refistribusi pendapatan yang tercermin dari belanja-belanja daerah sesuai fungsi, urusan, program dan kegiatannya melalui SKPD untuk meningkatkan disposable income masyarakat miskin. ${ }^{3} \quad$ Perbandingan capaian

\footnotetext{
${ }^{3}$ Analisis Pengaruh Belanja Daerah Menurut Klasifikasi Fungsi Terhadap Pengentasan Kemiskinan di Era Desentralisasi Fiskal (Studi Kasus Pada Kabupaten/Kota di Pulau
} 
Vol.04, No.02, Oktober 2018

Doi: $10.24198 / \operatorname{cosmogov.v2i2.xxxxx}$

outcome tersebut menjadi permasalahan yang harus dikupas secara mendalam. Didukung dengan beberapa penelitian yang peneliti gunakan, ditemukan bahwa tidak ada dampak signifikan pilkada langsung dengan kinerja pengelolaan anggaran yang lebih baik.

Problematika di atas menjadi bentuk indikasi masih kecilnya perhatian pemerintah Jawa Timur terhadap rakyat kecil merujuk pada visi, misi, dan program kerja yang telah dipaparkan pada awal pemerintahan. Beberapa contoh problematika yang terjadi di Jawa Timur selama periode pemerintahan Soekarwo dan Imam Utomo layak untuk dikaji lebih lanjut. Pasalnya, masing-masing mengemban tugas pada 'iklim' pemerintahan yang berbeda. Gubernur Imam Utomo memimpin Jawa Timur dari tahun 1998-2003 dan 2003-2008 yang pada saat itu masih era reformasi. Sedangkan Gubernur Soekarwo memegang tapuk kepimpinan pada tahun 2008-2013 dan 2013-2018 setelah penerapan kebijakan PILKADA. Sebelum tahun 2005, kepala daerah dan wakil kepala daerah dipilih oleh DPRD. Semenjak berlakunya UU No. 32 Tahun 2004, kepala daerah dapat dipilih langsung oleh rakyat melalui PILKADA.

Jawa/Bali Tahun 2008-2010) dalam Kajian Akademis BPPK Tahun Anggaran 2012

4 Debra W.Stewart. Professionalism VS Democracy, Friedriech VS Finner Revisited, Public Administration Quarterly, Vol. 9 No. 1 (SPRING, 1985), SPAEF, hl. 13-25

\section{PEMBAHASAN}

\section{Konsep Akuntabilitas}

Finner

menjelaskan

akuntabilitas sebagai konsep yang berkenaan dengan standar eksternal yang menentukan kebenaran suatu tindakan birokrasi. ${ }^{4}$ Luasnya ruang interpretasi atas makna substansial dari kata akuntabilitas, menimbulkan konsekuensi pada tingginya harapan publik atas anggaran yang akuntabel. Jika dirumuskan secara sederhana, anggaran yang berakuntabilitas adalah anggaran yang direncanakan sesuai dengan kebutuhan.

Akuntabilitas dapat dilihat sebagai suatu tingkatan dengan lima tahap yang berbeda yang diawali dari tahap yang lebih banyak membutuhkan ukuran-ukuran obyektif ke tahap yang membutuhkan lebih banyak ukuran subyektif. Tahap-tahap tersebut adalah: ${ }^{5}$

a) Probity and legality accountability

Hal ini menyangkut pertanggungjawaban

penggunaan dana sesuai dengan anggaran yang telah disetujui dan sesuai dengan peraturan perundangundangan yang berlaku.

b) Process Accountability Dalam hal ini digunakan proses. prosedur, atau ukuran

5 Arja Sadjiarto. Akuntabilitas dan Pengukuran Kinerja Pemerintahan, dalam Jurnal Akuntansi dan Keuangan Vol. 2 November 2000, hl. 138-150 
Vol.04, No.02, Oktober 2018

Doi: 10.24198/cosmogov.v2i2.xxxxx

dalam melaksanakan kegiatan yang ditentukan (planning, allocating, and managing).

c) Performance Accountability

Pada tingkatan ini dilihat apakah kegiatan yang dilakukan sudah efisien.

d) Program Accountability

Di sini akan disoroti penetapan dan pencapaian tujuan yang telah ditetapkan tersebut (outcomes and effectiveness).

e) Policy Accountability

Pada tahapan ini dilakukan pemiliihan berbagai kebijakan yang akan diterapkan atau tidak.

2. Akuntabilitas dan Analisis Belanja Publik (Public Expenditure Analysis)

Analisis belanja publik (Public Expenditure Analysis atau PEA) merupakan suatu cara menganalisis bagaimana pemerintah mengalokasikan dan mengelola sumber daya keuangan mereka. Tujuan melakukan analisis adalah memberikan rekomendasi tentang bagaimana pemerintah dapat mengelola keuangan publik secara lebih efisien dan efektif di masa yang akan datang. Semua pemerintah memiliki sumber daya yang terbatas. Dengan analisis ini, dapat ditemukan beberapa hal berikut ini:

a) Jumlah alokasi dana yang dibelanjakan pemerintah, serta berasal dari manakah dana tersebut. b) Tingkat efektifitas kerangka kerja dan proses perencanaan dan penyusunan anggaran.

c) Tujuan pembiayaan yang dilakukan oleh pemerintah

d) Kualitas layanan publik yang disediakan oleh pemerintah dari alokasi anggaran tersebut.

e) Sektor strategis yang menyediakan layanan secara berkualitas dan mana saja yang membutuhkan perbaikan

f) Siapa saja yang menerima manfaat utama dari pembelanjaan yang dilakukan pemerintah, apakah orang kaya atau orang miskin, perempuan atau laki-laki, dan wilayah terpencil atau perkotaan.

g) Tingkat persebaran manfaat alokasi anggaran tersebut.

h) Perbandingan akses pelayanan publik di pedesaan dan perkotaan.

i) Kualitas pengembangan sumber daya manusia ditilik dari tingkat kecakapan membaca, tingkat kematian, angka harapan hidup dan banyak lainnya.

Pada Peraturan Pemerintah Nomor 58 tahun 2005 tentang Pengelolaan Keuangan Daerah, dimana kebijakan pengelolaan keuangan daerah mempunyai sasaran agar pengeluaran pemerintah dapat teridentifikasi dengan jelas dan terukur mengenai apa yang ingin dicapai dalam satu tahun anggaran. 
Vol.04, No.02, Oktober 2018

Doi: $10.24198 /$ cosmogov.v2i2.xxxxx

Sasaran tersebut dituangkan dalam APBD yang memuat rencana keuangan yang diperoleh dan digunakan Pemerintah Daerah dalam melaksanakan tugas pemerintahan dan memberikan pelayanan kepada masyarakat. Salah satu tolok ukur yang dapat digunakan untuk memaksimalkan dan mengevaluasi anggaran belanja publik adalah dengan menggunakan konsep efisiensi alokatif ${ }^{6}$.

\section{Analisis Manfaat Belanja Pembangunan}

Provinsi Jawa Timur merupakan provinsi yang memiliki populasi cukup besar. Ini tentu menjadi tantangan menarik bagi pemerintah provinsi dalam mengatur agar mampu mencapai kinerja yang baik. Kinerja ini dapat diwujudkan melalui belanja pembangunan yang akuntabel, sehingga mampu efektif serta tepat sasaran bagi rakyat. Untuk menilai suatu pos belanja, maka diperlukan tren belanja selama beberapa periode.
${ }^{6}$ Mengukur Efisiensi dan Efektivitas Belanja Dalam Review Pelaksanaan Anggaran lihat artikel djpbjabar.net/index.php/keuangan-

\author{
Grafik 1
}

Tren Belanja Pembangunan

Provinsi Jawa Timur Tahun 2003-

2013

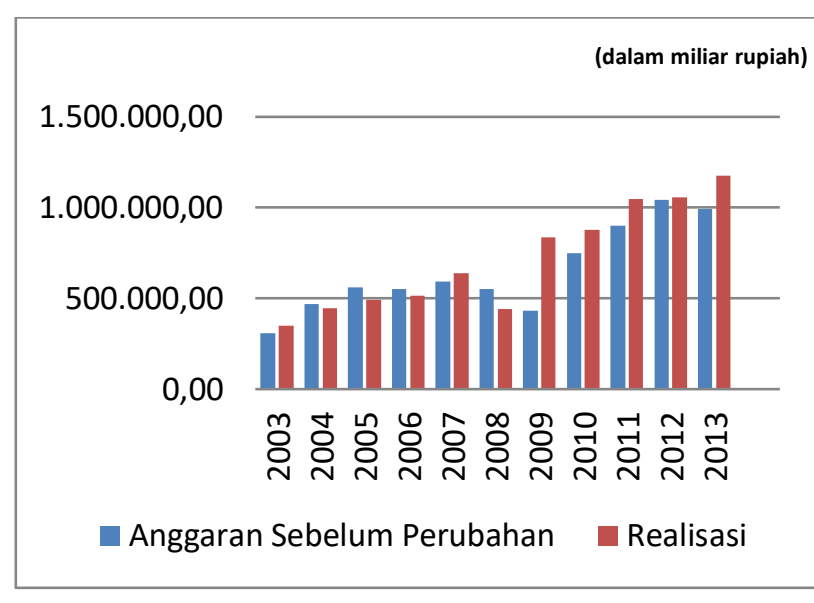

Rincian ringkasan belanja modal pemerintah provinsi Jawa Timur tahun 2004-2013 menunjukkan peningkatan yang cukup signifikan. Semenjak pemerintahan Imam Utomo, alokasi anggaran untuk belanja modal selalu mengalami peningkatan. Begitu juga pada pemerintahan Soekarwo, yang juga menunjukkan kenaikan cukup berarti. Namun, dibandingkan dengan masa pemerintaha Imam, Soekarwo ternyata lebih fokus mengalokasikan anggaran belanja modal, terbukti dengan realisasi dana selalu lebih tinggi daripada anggaran perencanaan.

Rincian ringkasan belanja modal pemerintah provinsi Jawa Timur tahun 2004-2013

publik/123-mengukur-efisiensi-danefektivitas-belanja-dalam-reviupelaksanaan-anggaran, diakses tanggal 10 Agustus 2016 
Vol.04, No.02, Oktober 2018

Doi: $10.24198 /$ cosmogov.v2i2.xxxxx

menunjukkan peningkatan yang cukup signifikan. Semenjak pemerintahan Imam Utomo, alokasi anggaran untuk belanja modal selalu mengalami peningkatan. Begitu juga pada pemerintahan Soekarwo, yang juga menunjukkan kenaikan cukup berarti. Namun, dibandingkan dengan masa pemerintaha Imam, Soekarwo ternyata lebih fokus mengalokasikan anggaran belanja modal, terbukti dengan realisasi dana selalu lebih tinggi daripada anggaran perencanaan.

Tabel 2

Persentase Perbandingan Belanja Pembangunan Dalam Anggaran Sebelum Perubahan Dengan

Realisasi Anggaran Provinsi Jawa Timur 2004-2013

\begin{tabular}{|c|c|}
\hline TAHUN & PERSENTASE \\
\hline $\mathbf{2 0 0 4}$ & -4.91 \\
\hline $\mathbf{2 0 0 5}$ & -14.24 \\
\hline $\mathbf{2 0 0 6}$ & -7.31 \\
\hline $\mathbf{2 0 0 7}$ & 7.50 \\
\hline $\mathbf{2 0 0 8}$ & -24.70 \\
\hline $\mathbf{2 0 0 9}$ & 48.32 \\
\hline $\mathbf{2 0 1 0}$ & 14.56 \\
\hline $\mathbf{2 0 1 1}$ & 13.86 \\
\hline $\mathbf{2 0 1 2}$ & 1.19 \\
\hline $\mathbf{2 0 1 3}$ & -58.00 \\
\hline
\end{tabular}

Sumber : Sumber : APBD Provinsi Jawa Timur Tahun 2003-2013 (data diolah)

Tabel di atas menunjukkan bahwa persentase realisasi belanja modal selalu lebih rendah daripada anggaran perubahan yang telah ditentukan. Artinya, alokasi dana tidak sesuai ekspektasi yang telah diperhitungkan. Dapat dilihat dari tabel di atas, dari tahun 2004 hingga 2008, hampir semua tahun mengalami penurunan realisasi, kecuali pada tahun 2007. Bahkan pada tahun 2008, realisasinya menurun hingga $24,70 \%$. Sebaliknya, tahun 2009-2012 dana realisasi selalu lebih tinggi. Sayangnya pada tahun 2013 kembali turun hingga 58\%.

Secara keseluruhan, pemerintah Provinsi Jawa Timur mengalokasikan belanja langsung pada beberapa urusan utama, antara lain kesehatan, pendidikan, pertanian, sosial dan tenaga kerja. Hasil dari kelima bidang urusan ini mampu menunjukkan tingkat keberhasilan pemimpin pada periodenya.

Tabel 3

Alokasi Belanja Pembangunan Tertinggi di Provinsi Jawa Timur 2003-2013

\begin{tabular}{|c|c|c|c|c|c|}
\hline $\begin{array}{c}\text { Tah } \\
\text { un }\end{array}$ & Kesehatan & Pendidikan & Pertanian & Sosial & $\begin{array}{c}\text { Tenaga } \\
\text { Kerja }\end{array}$ \\
\hline $\mathbf{2 0 0 3}$ & 493.106 & 2634013 & 128669 & 38342 & 34087 \\
\hline $\mathbf{2 0 0 4}$ & 319.605 & 259.233 & 78.299 & 47.210 & 46.134 \\
\hline $\mathbf{2 0 0 5}$ & 480.017 & 223.663 & 99.092 & 51.670 & 48.553 \\
\hline $\mathbf{2 0 0 6}$ & 506.444 & 239.391 & 117.157 & 62.381 & 53.711 \\
\hline $\mathbf{2 0 0 7}$ & 603.060 & 186.221 & 161.229 & 65.125 & 61.672 \\
\hline $\mathbf{2 0 0 8}$ & 686.911 & 225.790 & 204.224 & 93.724 & 75.795 \\
\hline $\mathbf{2 0 0 9}$ & 837.158 & 235.529 & 242.440 & 119.240 & 113.450 \\
\hline $\mathbf{2 0 1 0}$ & 1.237 .179 & 189.689 & 239.049 & 120.953 & 144.246 \\
\hline $\mathbf{2 0 1 1}$ & 1.692 .103 & 313.467 & 664.302 & 132.540 & 171.460 \\
\hline $\mathbf{2 0 1 2}$ & 1.838 .068 & 366.711 & 561.911 & 146.850 & 204.973 \\
\hline $\mathbf{2 0 1 3}$ & 2.070 .310 & 418.389 & 578.044 & 138.635 & 239.458 \\
\hline
\end{tabular}

Sumber : APBD Provinsi Jawa Timur

Tahun 2003-2013 (data diolah)

\section{Urusan Kesehatan}

Kesehatan adalah hak dasar manusia dan merupakan salah satu aspek penentu kualitas sumber daya manusia yang penting untuk 
Vol.04, No.02, Oktober 2018

Doi: $10.24198 /$ cosmogov.v2i2.xxxxx

dicermati. Mengingat pentingnya peranan kesehatan dalam investasi sumber daya manusia, maka upaya pemenuhan kesehatan perlu untuk semua penduduk, mulai usia dini serta berkesinambungan. Artinya pemenuhan kesehatan yang baik, yaitu bayi yang masih dalam kandungan, pasca kelahiran, masa balita, usia dewasa dan tua. Hal lain yang berpengaruh pada kualitas kesehatan masyarakat adalah kondisi lingkungan, status gizi, dan bagaimana berperilaku hidup sehat. Perbaikan pelayanan kesehatan pada dasarnya merupakan suatu investasi sumber daya manusia untuk mencapai masyarakat yang sejahtera. Tingkat kesehatan masyarakat akan sangat berpengaruh terhadap tingkat kesejahteraan masyarakat, karena tingkat kesehatan memiliki keterkaitan yang erat dengan kemiskinan. Sementara itu, tingkat kemiskinan akan terkait dengan tingkat kesejahteraan. Oleh karena kesehatan merupakan faktor utama kesejahteraan masyarakat yang hendak diwujudkan pemerintah, maka kesehatan harus menjadi perhatian utama pemerintah sebagai penyelenggara pelayanan publik. Pemerintah harus dapat menjamin hak masyarakat untuk sehat dengan memberikan pelayanan kesehatan secara adil, merata, memadai, terjangkau, dan berkualitas.
Grafik 2

\section{Tren Belanja Kesehatan Provinsi} Jawa Timur Tahun 2003-2008

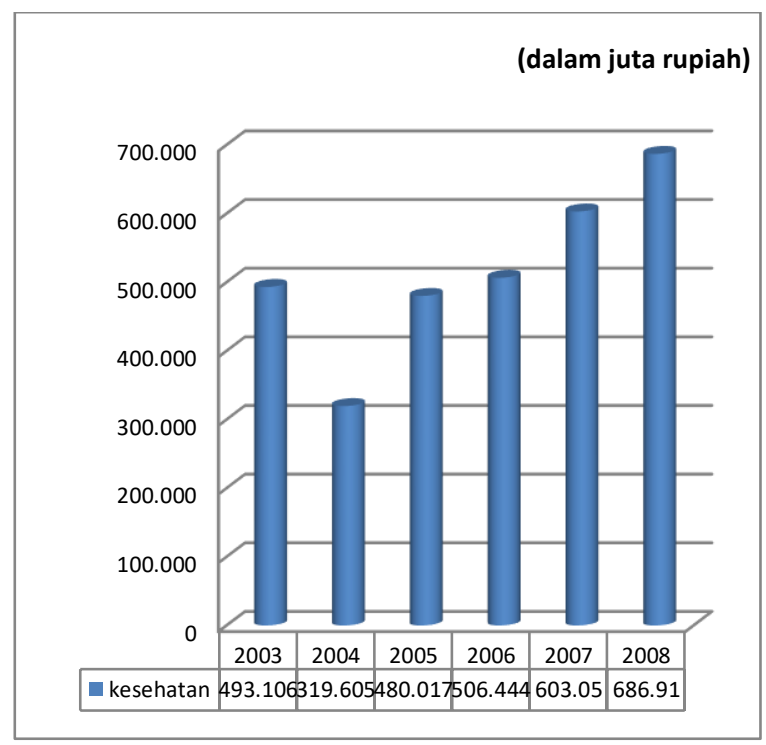

Sumber : APBD Provinsi Jawa Timur Tahun 2003-2008 (data diolah)

Dari grafik di atas dapat dilihat sejak tahun 2004 hingga 2008, jumlah alokasi dana selalu meningkat. Hal ini membuktikan bahwa masa pemerintahan Imam Utomo juga membuktikan keseriusannya mengabdi pada rakyat dengan mengalokasikan dana pada urusan kesehatan dengan peningkatan yang sangat signifikan. Jika dirunut, sejak tahun 2004 hingga 2008, persentase kenaikan yang telah diraih sebesar $115 \%$ dari alokasi anggaran kesehatan pada tahun 2004. 
Vol.04, No.02, Oktober 2018

Doi: $10.24198 /$ cosmogov.v2i2.xxxxx

\section{Grafik 3}

\section{Kesehatan Provinsi Jawa Timur}

Tahun 2008-2013

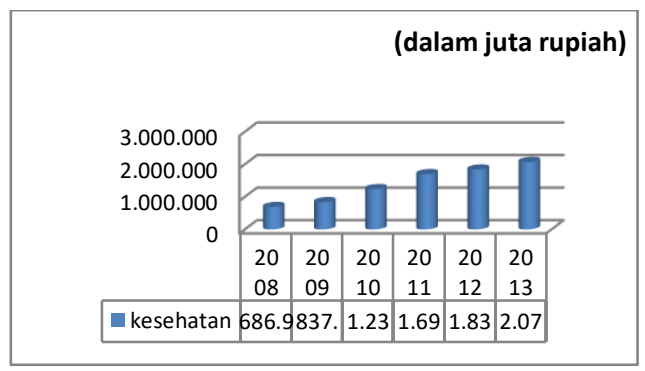

Sumber : APBD Provinsi Jawa Timur Tahun 2008-2013 (data diolah)

Grafik di atas menunjukkan alokasi belanja kesehatan selama tahun 2009 hingga 2013 selalu mengalami peningkatan dengan nominal yang cukup besar. Peningkatan tersebut cukup drastis mengingat pada tahun 2009 nominalnya berkisar 837.158, sedangkan pada tahun 2013 mencapai 2.070.310. Artinya, persentase kenaikan selama 5 tahun tersebut mencapai $147 \%$. Dengan besarnya alokasi tersebut, diharapkan mampu semakin memperbaiki kualitas kesehatan untuk seluruh khalayak masyarakat.

\section{Urusan Pendidikan}

Dalam UU Nomor 20/2003 tentang sistem pendidikan nasional disebutkan bahwa setiap warga negara mempunyai hak yang sama untuk memperoleh pendidikan yang bermutu. Pembangunan pendidikan merupakan kegiatan investasi pada sumber daya manusia. Semakin banyak terciptanya SDM yang berkualitas di suatu daerah, maka kedepannya akan menguntungkan daerah yang memiliki aset pembangunan tersebut. Masalah pendidikan bagi Provinsi Jawa Timur menjadi skala prioritas pembangunan.

Grafik 4

\section{Tren Belanja Pendidikan Provinsi Jawa Timur Tahun 2003-2008}

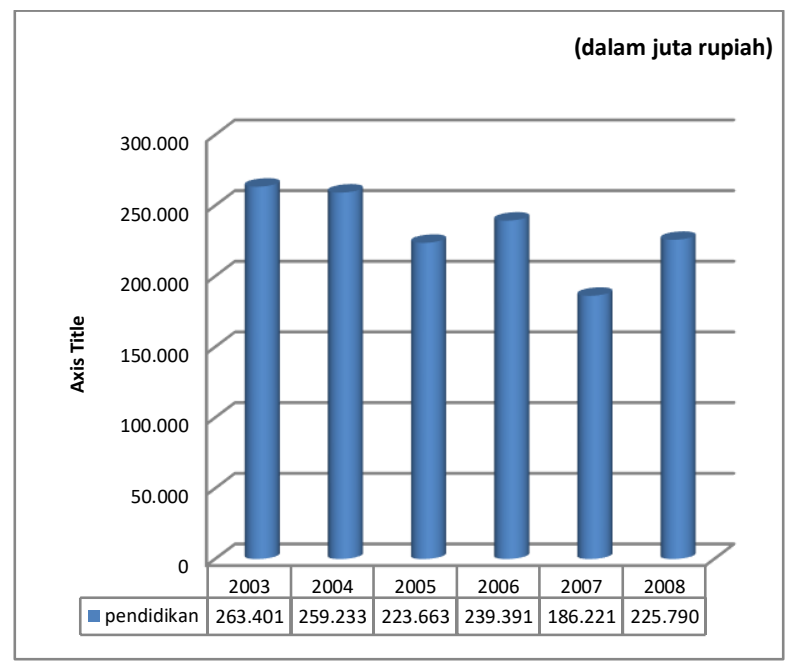

Sumber : APBD Provinsi Jawa Timur Tahun 2003-2008 (data diolah)

Secara keseluruhan,nominal belanja pendidikan selama pemerintahan imam utomodari tahun 2003-2008 mengalami penurunan sebesar $13 \%$ jika dibandingkan dengan jumlah awal. Padahal harapannya setiap tahun alokasi belanja pendidikan harus selalu meningkat.

\section{Grafik 5}

\section{Belanja Pendidikan Provinsi Jawa} Timur Tahun 2008-2013

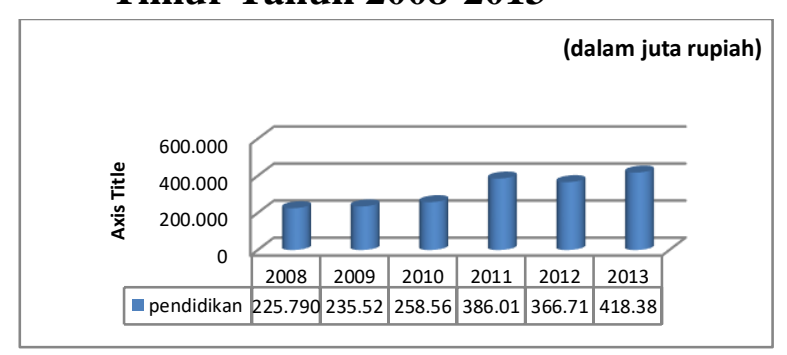


Vol.04, No.02, Oktober 2018

Doi: 10.24198/cosmogov.v2i2.xxxxx

Sumber : APBD Provinsi Jawa Timur Tahun 2008-2013 (data diolah)

Dapat dilihat pada grafik di atas, terlihat kenaikan nominal yang cukup besar. Dimulai tahun 2009 mencapai 235,529, lalu meningkat menjadi 258,566 di tahun 2010 . Diikuti tahun 2011 sebesar 386,016, 366,711 (2012) dan 418,389 (2013). Persentase kenaikan tersebut mencapai $78 \%$ dari alokasi belanja tahun 2009. Hal ini membuktikan keseriusan pemerintahan Soekarwo dalam mengawal peningkatan pendidikan untuk seluruh rakyat Jawa Timur. Semakin besar dana yang dikucurkan untuk belanja pendidikan, maka makin besar pula peningkatan indeks pembangunan manusia. Jawa Timur memfokuskan pembangunan pendidikan pada 3 hal yaitu sebagai berikut:

a. Menata sistem pembiayaan pendidikan yang berprinsip keadilan, efisien, transparan dan akuntabel, serta peningkatan anggaran pendidikan mencapai $20 \%$ APBD

b. Memberikan akses lebih besar kepada kelompok masyarakat yang selama ini kurang dapat terjangkau oleh layanan pendidikan yang murah dan bermutu

c. Menuntaskan pelaksanaan Wajib Belajar Pendidikan Dasar Sembilan Tahun, dan Pendidikan Menengah 12 Tahun

\section{Urusan Tenaga Kerja}

Jawa Timur sebagai salah satu Provinsi yang jumlah angkatan kerjanya terbesar diposisikan akan mengalami bonus demografi.

Grafik 6

Tren Belanja Tenaga Kerja

Provinsi Jawa Timur Tahun 2003-

2013

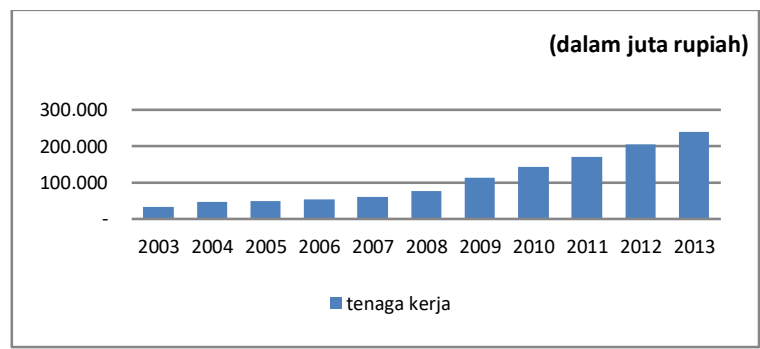

Sumber : APBD Provinsi Jawa Timur Tahun 2003-2013 (data diolah)

Semenjak tahun 2004-2013, anggaran belanja tenaga kerja terus meningkat secara signifikan. Bahkan kenaikan yang terjadi mulai tahun 2013 mencapai empat kali lipat alokasi belanja tenaga kerja pada tahun 2004. Ini membuktikan Soekarwo berusaha memanfaatkan banyaknya penduduk di Jawa Timur untuk meningkatkan kualitas sumber daya manusia yang bisa bersaing.

\section{Grafik 7}

Pencari Kerja Terdaftar, Lowongan Kerja Terdaftar dan Penempatan/Pemenuhan Tenaga Kerja Jawa Timur Tahun 2004-

2013

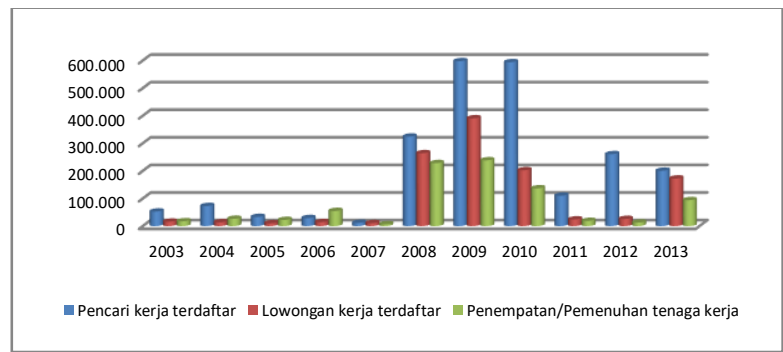


Vol.04, No.02, Oktober 2018

Doi: $10.24198 /$ cosmogov.v2i2.xxxxx

Sumber: www.jatim.bps.go.id (data diolah)

Hal yang seringkali menjadi masalah pada sektor tenaga kerja adalah minimnya lapangan pekerjaan namun pencari kerja sangat melimpah. Ini bisa tergambar pada grafik di atas yang menunjukkan lowongan kerja terdaftar dan penempatan atau pemenuhan tenaga kerja selalu lebih rendah daripada pencari kerja terdaftar. Namun perlu diperhatikan adanya lonjakan jumlah pencari kerja, lowongan kerja dan penempatan kerja pada tahun 2008 , 2009 dan 2010.

Dengan

demikian, pengangguran masih menjadi isu utama yang berpotensi menimbulkan persoalan dan kerawanan yang sangat mempengaruhi sendi-sendi kehidupan sosial maupun ekonomi masyarakat. Pengangguran terjadi antara lain disebabkan: ${ }^{7}$

a. tidak imbangnya pertumbuhan angkatan kerja dengan kesempatan kerja

b. terbatasnya kesempatan kerja yang dipengaruhi oleh pertumbuhan ekonomi

c. masih rendahnya kualitas angkatan kerja

d. kesenjangan persediaan tenaga kerja dengan kebutuhan akan tenaga kerja yang sesuai

e. motivasi dan jiwa kewirausahaan untuk

7 Dinas Tenaga Kerja Transmigrasi dan Kependudukan Provinsi Jawa Timur dalam menciptakan lapangan kerja baru masih rendah

\section{Pertumbuhan Ekonomi}

Produk Domestik Regional Bruto (PDRB) merupakan salah satu indikator penting untuk mengetahui kondisi ekonomi di suatu daerah dalam suatu periode tertentu, baik atas dasar harga berlaku maupun atas dasar harga konstan. PDRB pada dasarnya merupakan jumlah nilai tambah yang dihasilkan oleh seluruh unit usaha dalam suatu daerah tertentu, atau merupakan jumlah nilai barang dan jasa akhir yang dihasilkan oleh seluruh unit ekonomi pada suatu daerah.

\section{Grafik 8}

Produk Domestik Regional Bruto Atas Dasar Harga Berlaku 20042013

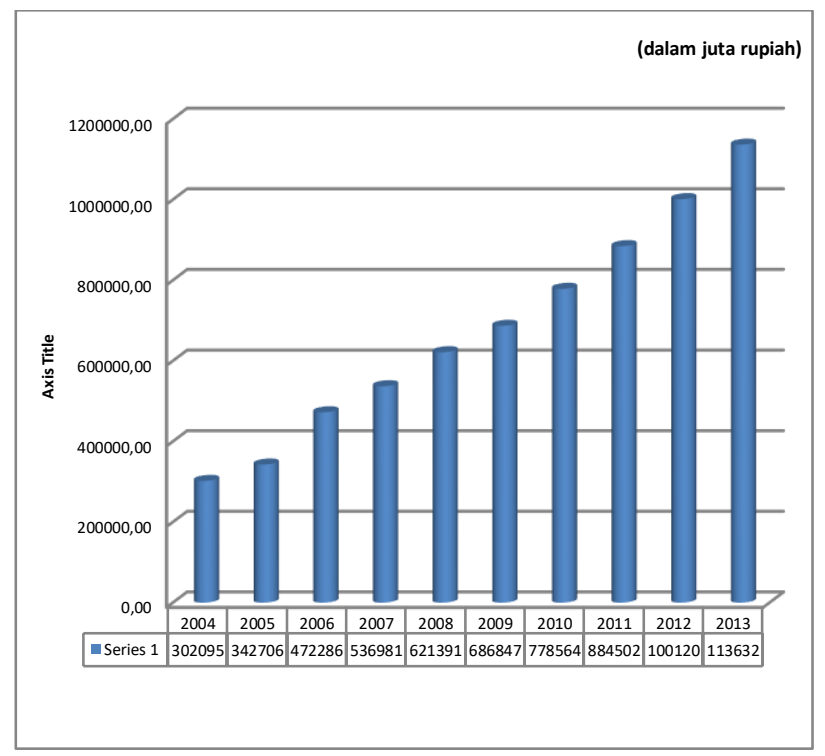

Sumber : www.jatim.bps.go.id (data diolah)

Laporan Akuntabilitas Kinerja Instansi Pemerintah (LAKIP) Tahun 2013 
Vol.04, No.02, Oktober 2018

Doi: $10.24198 /$ cosmogov.v2i2.xxxxx

\section{Grafik 9}

\section{Produk Domestik Regional Bruto} Atas Dasar Harga Konstan 2000

Tahun 2004-2013

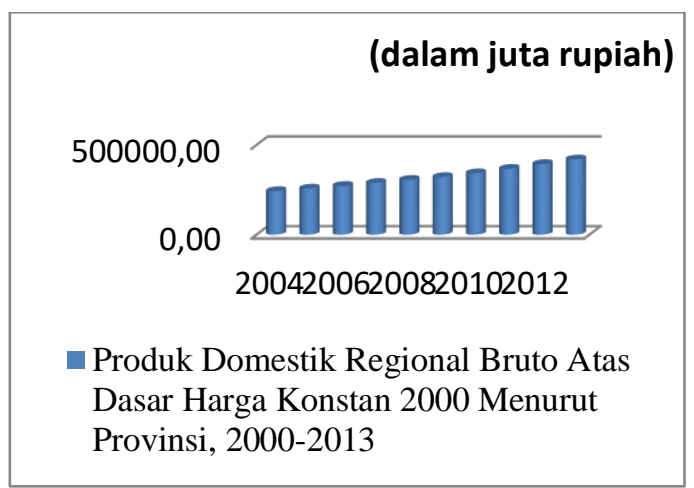

Sumber : www.jatim.bps.go.id (data diolah)

Berdasarkan PDRB atas harga konstan 2000, grafik di atas menunjukkan kecenderungan pertumbuhan ekonomi Jawa Timur terus membaik, meski pada 2006 terjadi sedikit perlambatan dibanding 2005, namun pada 2007 pertumbuhan ekonomi Jawa Timur meningkat kembali. Perlambatan pertumbuhan ekonomi pada 2006, antara lain, disebabkan dampak negatif kenaikan harga BBM dua kali, dan cukai rokok pada 2005, serta ditambah dampak luapan lumpur panas Lapindo. Pada 2004, pertumbuhan ekonomi Jawa Timur hanya sebesar 5,83\%, kemudian meningkat tipis menjadi $5,84 \%$ pada 2005. Pertumbuhan ekonomi melambat menjadi 5,80\% pada 2006, namun pada tahun berikutnya (2007) meningkat menjadi $6,11 \%$. Tapi pada 2008 , pertumbuhan ekonomi kembali melambat menjadi

\footnotetext{
${ }^{8}$ www.blh.jatimprov.go.id Diakses pada tanggal 1 November 2016
}

$5,90 \%$, meski masih di atas angka pertumbuhan 2005.

Melemahnya pertumbuhan ekonomi 2008 antara lain disebabkan dampak krisis ekonomi global. Perkembangan PDRB per kapita tahun dasar 2000 periode 2003-2007 menunjukkan kecenderungan terus meningkat, karena pertumbuhan PDRB ADHB lebih cepat daripada pertumbuhan penduduk. Kenaikan harga BBM pada 2005 ternyata relatif tidak menghambat pergerakan kenaikan PDRB per kapita, sehingga pada tahun tersebut mampu meningkat menjadi Rp 11,06 juta. Perkembangan PDRB per kapita tahun dasar 2000 periode 2003-2007 menunjukkan kecenderungan terus meningkat, karena pertumbuhan PDRB ADHB lebih cepat daripada pertumbuhan penduduk. Pada 2003, PDRB per kapita Jawa Timur mencapai Rp 8,30 juta, kemudian meningkat menjadi Rp 9,40 juta pada 2004. Kenaikan harga BBM pada 2005 ternyata relatif tidak menghambat pergerakan kenaikan PDRB per kapita, sehingga pada tahun tersebut mampu meningkat menjadi Rp 11,06 juta. ${ }^{8}$

\section{Kemiskinan}

Grafik persentase penduduk miskin Provinsi Jawa Timur memang menurun dari tahun ke tahun. Pada tahun 2004, persentasenya mencapai 20,08 lalu turun hingga 18,51 pada 
Vol.04, No.02, Oktober 2018

Doi: $10.24198 /$ cosmogov.v2i2.xxxxx

tahun 2008. Sedangkan pada tahun 2009 mencapai 16,68 lalu turun hingga 12,73 persen. Pemerintah Soekarwo yang terkenal mengusung program pengentasan kemiskinan rupanya mampu membuktikan kinerjanya dengan baik. Pada periode 2009-2013 dapat mengurangi persentase penduduk miskin hingga 3,95 persen, hampir dua kali lipat dari hasil yang diraih oleh Imam Soenaryo.

Grafik 10

\section{Persentase Penduduk Miskin Provinsi Jawa Timur Tahun 2004-} 2013

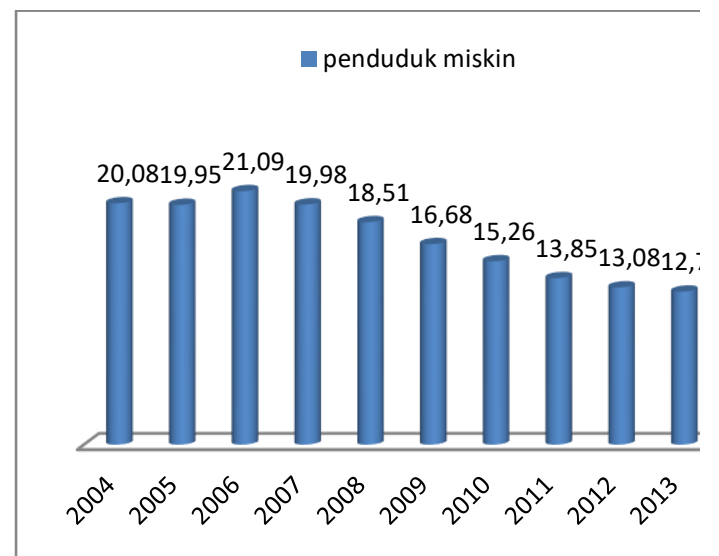

Sumber : www.jatim.bps.go.id (data diolah)

Kemiskinan dipahami tak hanya sebatas masalah kemampuan ekonomi, tapi juga kegagalan memenuhi hak-hak dasar, dan perbedaan perlakuan bagi seseorang atau sekelompok orang untuk bisa menjalani kehidupan secara bermartabat. Hak-hak dasar yang harus terpenuhi adalah kebutuhan pangan, kesehatan, pendidikan, pekerjaan, perumahan, air bersih, pertanahan, sumber daya alam dan lingkungan hidup, rasa aman dari perlakuan atau ancaman tindak kekerasan, serta hak berpartisipasi dalam kehidupan sosial politik, baik bagi laki-laki maupun perempuan. Berbagai upaya sudah dilakukan Pemerintah Propinsi Jawa Timur untuk mengentas masyarakat miskin, mulai dari bantuan dan perlindungan sosial rumah tangga miskin hingga pemberdayaan usaha mikro dan kecil (UMK).

\section{Kontribusi Pilkada Pada Akuntabilitas Belanja Langsung Pemerintah Provinsi Jawa Timur}

Salah satu pilar penting dalam penyelenggaraan kebijakan otonomi daerah adalah desentralisasi fiskal yang dilaksanakan melalui kebijakan perimbangan keuangan antara pusat dan daerah. Pendanaan pembangunan melalui transfer ke daerah merupakan bagian yang tidak terpisahkan dari pendanaan pembangunan secara nasional. Pengelolaan pendanaan transfer ke daerah senantiasa didorong untuk memenuhi pelaksanaan tata kelola keuangan yang baik, memiliki kinerja terukur dan memiliki akuntabilitas terhadap masyarakat. Hasil akhir yang diharapkan adalah adanya peningkatan pelayanan publik.

Hal ini sejalan dengan tujuan dilaksanakannya kebijakan otonomi daerah dan desentralisasi fiskal yang diharapkan dapat memiliki dampak yang signifikan terhadap peningkatan perekonomian di daerah, yang 
Vol.04, No.02, Oktober 2018

Doi: $10.24198 /$ cosmogov.v2i2.xxxxx

ditandai dengan peningkatan

pelayanan publik, baik secara kuantitas maupun kualitas yaitu sebuah pelayanan publik yang mampu memenuhi dua hal pokok yaitu pelayanan yang dapat memberikan kepuasan kepada publik dan pelayanan yang memenuhi standar pelayanan minimum (minimum local public service delivery standards). Dengan demikian, peningkatan pelayanan publik dapat mendorong pembangunan ekonomi yang pada akhirnya kesejahteraan masyarakat (social welfare) akan menjadi lebih

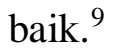

Salah satu tugas penting dari pemerintahan daerah adalah menyediakan pelayanan dan membangun infrastruktur publik melalui alokasi dan pelaksanaan belanja pada Anggaran Pendapatan dan Belanja Daerah (APBD). Salah satu tolok ukur yang dapat digunakan untuk melihat kinerja belanja daerah yaitu didasarkan pada pendekatan tingkat penyerapan belanja. Semakin besar tingkat penyerapan, dianggap semakin optimal kinerja belanjanya, dan sebaliknya semakin rendah tingkat penyerapan semakin rendah pula kinerja belanja suatu pemerintah daerah. Penyerapan belanja APBD mengindikasikan kecepatan daerah dalam menggunakan dananya untuk pelayanan ke masyarakat.

\footnotetext{
${ }^{9}$ Kementerian Keuangan Republik Indonesia dalam Laporan Spending Performance dalam Mendanai Pelayanan Publik
}

\section{Perbandingan Akuntabilitas \\ Belanja Pembangunan Pada Masa Pemerintahan Imam Utomo- Soenaryo dengan Soekarwo- Syaifullah Yusuf}

Pemerintahan Imam UtomoSoenaryo dan Soekarwo-Syaifullah lahir dari cara pemilihan gubernur yang sangat berbeda. Gubernur Soekarwo merupakan gubernur pertama produk dari diterapkannya pilkada langsung di Provinsi Jawa Timur. Sedangkan, Imam Utomo masih dipilih melalui DPRD pada saat sebelum diterapkannya pilkada langsung. Perbedaan cara pemilihan ini membawa harapan yang cukup besar mampu menghasilkan era kepemimpinan yang lebih baik. Salah satu cara mengukurnya dengan membandingkan akuntabilitas belanja pembangunan pada dua era pemerintahan tersebut. Efektif atau tidaknya alokasi belanja pembangunan umumnya dilihat dari outcome yang dihasilkan pemerintahan tersebut. Outcome tersebut bisa ditilik dari indeks pembangunan manusia jawa timur.

Salah satu cara untuk mengukur keberhasilan atau kinerja suatu wilayah dalam bidang pembangunan manusia dapat dilihat dari output berupa Indeks Pembangunan Manusia. Hal ini telah dipaparkan dengan jelas pada PP No. 8 Tahun 2008, yang mana Indeks 
Vol.04, No.02, Oktober 2018

Doi: $10.24198 /$ cosmogov.v2i2.xxxxx

Pembangunan Manusia menjadi Evaluasi Kinerja Pelaksanaan Otonomi Daerah (EKPOD). Evaluasi ini bertujuan mengukur kualitas penerapan otonomi daerah yang ditunjukkan dari tinggi rendahnya kualitas manusia. Parameter ini secara internasional diukur dengan indeks pembangunan manusia. Dalam EKPOD, IPM ini digunakan untuk mengecek apakah aspek-aspek yang digunakan untuk mengukur kemampuan penyelenggaraan otonomi daerah dapat dipertanggungjawabkan. Dengan demikian IPM idealnya menjadi salah satu indikator pengukuran kinerja daerah dilihat dan sisi outcomes.

Pembangunan manusia dapat dilihat juga sebagai pembangunan manusia dapat dilihat juga sebagai pembangunan kemampuan melalui perbaikan taraf kesehatan, pengetahuan, dan keterampilan, sekaligus pemanfaatan kemampuan tersebut. Konsep pembangunan ini jauh lebih luas pengertiannya dibandingkan konsep pembangunan ekonomi yang menekankan pada pertumbuhan ekonomi, kebutuhan dasar, kesejahteraan masyarakat dan pengembangan sumber daya manusia.

Tabel 4

Perbandingan Indeks

Pembangunan Manusia Era

Pemerintaha Imam Utomo (2003-

2008) dengan Soekarwo (20082013)

\begin{tabular}{|c|c|}
\hline $\begin{array}{c}\text { Imam Utomo } \\
\mathbf{2 0 0 3 - 2 0 0 8}\end{array}$ & $\begin{array}{c}\text { Soekarwo } \\
\mathbf{2 0 0 8 - 2 0 1 3}\end{array}$ \\
\hline 4.78 & 2.45 \\
\hline
\end{tabular}

Sumber : www.jatim.bps.go.id (data diolah)

Dari tabel di atas, dapat diketahui bahwa persentase kenaikan IPM pada masa pemerintahan Imam Utomo jauh lebih signifikan daripada masa Gubernur Soekarwo. Hal ini tentu sangat disayangkan jika IPM mengalami penurunan daripada masa pemerintahan sebelumnya. Padahal, pada Rencana Pembangunan Jangka Menengah Daerah, visi misi Soekarwo jelas untuk mengedepankan mewujudkan kemakmuran bersama 'wong cilik'. Visi misi tersebut diarahkan dengan mengentaskan kemiskinan melalui pemenuhan pelayanan kebutuhan dasar rakyat. Kebutuhan dasar rakyat mencakup pendidikan, kesehatan dan tingkat kelayakan ekonomi. Namun, hasil kerja yang telah dipaparkan nyatanya masih belum terlalu memuaskan. Gubernur Soekarwo belum benar-benar fokus dalam mewujudkan visi misinya yang berkaitan dengan indeks pembangunan manusia.

Perbandingan Penyerapan Anggaran Pada Pemerintahan Imam Utomo-Soenaryo dan Soekarwo-Syaifullah Yusuf

Dari seluruh paparan sebelumnya, bisa ditarik kesimpulan bahwa tidak ada dampak khusus akan penerapan pilkada langsung pada 
Vol.04, No.02, Oktober 2018

Doi: 10.24198/cosmogov.v2i2.xxxxx

tingkat akuntabilitas belanja langsung provinsi Jawa Timur. Justru capaian yang telah diraih oleh masa pemerintahan Imam-Soenaryo jauh lebih baik daripada periode Soekarwo dan Syaifullah yang merupakan produk hasil pilkada langsung. Meskipun alokasi belanja modal pada tahun 2008-2013 memang jauh lebih besar, bahkan hampir meningkat dua kali lipat daripada era pemerintahan sebelumnya, sayangnya belum mampu membawa perubahan yang cukup memuaskan. Pada beberapa sektor memang terjadi peningkatan, namun kenaikannya masih lebih besar dibanding yang telah diraih Imam Utomo.

Tabel 5

Kabupaten/Kota Dengan Hasil Indeks Pembangunan Manusia Terendah di Provinsi Jawa Timur 2003-2013

\begin{tabular}{|c|c|}
\hline No. & Kabupaten/Kota \\
\hline 1 & Sampang \\
\hline 2 & Bondowoso \\
\hline 3 & Situbondo \\
\hline 4 & Probolinggo \\
\hline 5 & Bangkalan \\
\hline
\end{tabular}

Sumber : www.jatim.bps.go.id (data diolah)

Dari tabel di atas, dapat dilihat ada 5 kabupaten/kota yang memiliki Indeks Pembangunan Manusia rendah selama tahun 2003-2013. Jika diamati, kelima daerah di atas

10 Jimmy Ventius Parluhutan, Strategi Optimalisasi Penyerapan Anggaran Kota memang terkendala oleh kondisi geografis dalam mencapai daerah tersebut. Sulitnya akses menuju daerah tersebut, nyatanya juga menjadi faktor dalam mempengaruhi penyerapan suatu daerah.

Permasalahan mengenai minimnya penyerapan anggaran di pemerintahan daerah, kementerian dan lembaga kerap kali dituding sebagai buruknya kinerja birokrasi. Penyerapan anggaran sendiri memang penting untuk mendorong terciptanya multiplier effect terhadap ekonomi. Kegagalan target penyerapan anggaran memang akan berakibat hilangnya manfaat belanja. Karena dana yang telah dialokasikan ternyata tidak semuanya dapat dimanfaatkan yang berarti terjadi dana yang menganggur. Penyerapan anggaran secara umum hanya memiliki akselesari tinggi pada saat akhir tahun. Sedangkan di awal tahun, umumnya sulit direalisasikan sebagaimana yang diharapkan publik, bahkan tidak sedikit institusi yang kurang memiliki daya serap anggaran pada awal hingga pertengahan tahun anggaran. ${ }^{10}$

Persoalan rendahnya penyerapan anggaran yang berdampak pada rendahnya IPM terjadi akibat beberapa faktor, antara lain:

$$
\begin{array}{lr}
\text { a. Lambatnya } & \text { penyerapan } \\
\text { anggaran } & \text { juga } \\
\text { mengindikasikan } & \text { bahwa }
\end{array}
$$

Bogor, dalam Jurnal Sekolah Pascasarjana Institut Pertanian Bogor 2016 
Vol.04, No.02, Oktober 2018

Doi: 10.24198/cosmogov.v2i2.xxxxx

memang sejumlah institusi tidak punya konsep perencanaan yang matang, jelas dan terukur.

b. Tidak adanya konsep perencanaan penggunaan anggaran secara riil tentu akan berdampak pada munculnya sejumlah kesulitan dalam mengarahkan penggunaan anggaran dengan tepat sasaran.

c. Kurangnya pemahaman sejumlah aparatur di berbagai institusi terkait dengan mekanisme penggunaan anggaran dan model pertanggungjawabannya.

Atas dasar ini, maka kemudian lahirlah sikap ketakutanyang berlebihan karena tidak memahami secara utuh akan dasar hukum penggunaan anggaran yang berada dalam wilayah kewenangannya. Sementara di sisi lain, tidak ada alasan bagi mereka yang melakukan kesalahan dan kelalaian dalam pengelolaan dan penggunaan anggaran, yang atas kesalahan dan kelalaian tersebut bisa dijerat dengan hukuman pidana korupsi. Atas berbagai persoalan itulah, maka kemudian sejumlah institusi lebih

11 Jurnal Pembangunan Daerah Edisi Juni 2015 Tahun VI memilih berdiam diri manakala tidak memahami secara utuh mekanisme penggunaan anggaran secara utuh dan menyeluruh. ${ }^{11}$

d. Akibat lemahnya koordinasi antara perencanaan dan pelaksanaan dapat berakibat lemahnya penyerapan anggaran. Terutama untuk kegiatan-kegiatan, seperti pembangunan gedung baru, di mana pada tahap perencanaan ternyata tidak dialokasikan anggaran untuk pembebasan lahan. Sedangkan untuk kegiatan seperti pelatihan dan pendidikan ternyata tidak dialokasikan anggaran untuk peIjalanan dinas bagi peserta pelatihan. Anggaran yang tersedia hanya untuk pengeluaran konsumsi, honor pengajar dan lump-sum peserta. $^{12}$

e. Lemahnya IPM juga mengindikasinya masih banyak penduduk provinsi Jawa Timur yang kesulitan mengakses pelayanan publik dasar, yaitu kesehatan dan pendidikan. Terutama di daerah terpencil yang sulit diakses, tentu lokasi seperti ini sering mengalami kesulitan dalam mendapatkan

12 Adrianus dan Sri Lestari, Faktor-Faktor Penyebab Rendahnya Penyerapan Belanja Kementerian/Lembaga TA 2010 
Vol.04, No.02, Oktober 2018

Doi: 10.24198/cosmogov.v2i2.xxxxx

pelayanan publik yang optima.

\section{Analisis Perbandingan Dasar} Hukum Keuangan Daerah

PP 58 tahun 2005 tentang

Pengelolaan Keuangan Daerah, merupakan salah satu peraturan operasional dalam implementasi Otonomi Daerah, setelah era reformasi tata kelola keuangan negara/daerah yang ditandai dengan disahkannya paket undang-undang bidang keuangan negara. PP ini telah mendorong Daerah-daerah untuk melakukan perubahan dan perbaikan dalam manajemen dan pengelolaan keuangan

Daerah. Dengan manajemen Keuangan Daerah yang sehat diharapkan transparansi dan akuntabilitas pemerintah daerah di bidang keuangan akan lebih terukur. Upaya ini harus mendapat dukungan dari semua pihak karena merupakan salah satu tuntutan reformasi yang menekankan pada upaya penyelenggaraan pemerintahan yang bersih dan tata pemerintahan yang baik.
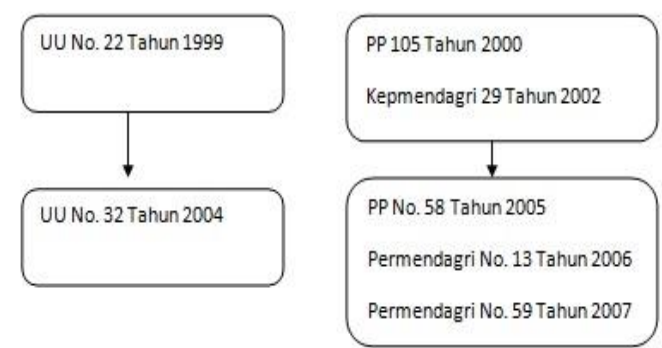

Pada awalnya, kemunculan Permendagri No. 13/2006 sangat ditunggu-tunggu semua kalangan, khususnya pemerintah daerah, karena diharapkan akan memberikan kejelasan dan kepastian dalam pengelolaan keuangan daerah. Namun yang terjadi adalah sebaliknya, dikeluarkannya Permendagri No. 13/2006 semakin menambah ketidakjelasan dan kebingungan daerah dalam mencari bentuk tata kelola keuangan daerah. Peraturan ini kurang memiliki landasan konsepsional yang kuat sehingga dikhawatirkan tidak konsisten dalam implementasinya. Harapan untuk menciptakan pengelolaan keuangan daerah yang ekonomis, efisien, efektif, transparan dan akuntabel melalui anggaran berbasis kinerja justru menjadi sulit diraih. Kemendagri yang secara historis merupakan pengontrol pemerintah daerah, tidak rela kehilangan kekuasaannya yang begitu besar dengan adanya otonomi daerah. Dengan dilandasi PP 58 Tahun 2005, Kemendagri telah mengeluarkan produk hukum yang sangat membingungkan daerah. Kenyataan yang terjadi menunjukkan bahwa Permendagri No. 13/2006 seolah-olah disusun dengan konsep yang kurang matang dalam waktu yang terburuburu. Dalam hal ini, terkesan tidak ada koordinasi di tingkat pemerintah pusat dan daerah dalam membuat dan menetapkan peraturan pelaksanaan 
Vol.04, No.02, Oktober 2018

Doi: $10.24198 /$ cosmogov.v2i2.xxxxx

pada tingkat operasional yang lebih rendah. ${ }^{13}$

Permendagri no. 13/2006 masih banyak mengandung ketidakjelasan dan ketidaktegasan dalam memberikan pedoman kepada daerah. Hal ini mengakibatkan kebingungan pemerintah daerah dalam pengelolaan keuangannya. Dalam proyeksi perkembangan demokratisasi di republik Indonesia, negara ini menerapkan sistem otonomi daerah dengan asas desentralisasi. Namun ditinjau dari model hubungan keuangan yang telah ditetapkan, nampak sangat jelas bahwa pemerintah daerah terkesan pasif dalam proses ini. Pemerintah pusat terkesan masih mendikte pemerintah daerah dalam pembagian dana perimbangan. Penetapan pembagian Dana bagi hasil oleh pemerintah pusat terkesan sangat sentralistik.

\section{KESIMPULAN}

Pilkada secara langsung, seperti halnya pemilihan umum, merupakan arena masyarakat politik, tempat bagi masyarakat untuk mengorganisir kekuasaan dan meraih kontrol atas pemimpin terpilih. Pada dasarnya, alokasi belanja untuk pembangunan pada masa Soekarwo memang lebih besar daripada periode Imam Utomo. Meskipun alokasi belanja modal pada tahun 2008-2013 memang jauh lebih besar, namun belum mampu membawa perubahan yang cukup

${ }^{13}$ Harian Tribun Timur, Kamis, 23 Maret 2007 memuaskan. Penyerapan dana alokasi belanja pembangunan pada era Imam Utomo ternyata lebih baik daripada era Soekarwo. Hasil indeks pembangunan manusia sebagai outcome keberhasilan kinerja pemerintah daerah ternyata menunjukkan capaian indeks yang lebih baik pada masa Imam Utomo, yang merupakan pemimpin yang bukan dipilih melalui pilkada langsung. Hal ini menunjukkan pencapaian IPM juga erat kaitannya dengan tingkat penyerapan anggaran daerah.

Analisis perbandingan peraturan keuangan daerah Kepmendagri No. 29 tahun 2002 dan permendagri no. 13 tahun 2006, menemukan bahwa produk hukum yang dikeluarkan oleh pemerintah pusat cenderung mengikat pemerintah daerah dalam mengelola keuangan sesuai kebutuhan publik. Perubahan mendasar pada struktur belanja, menjadi belanja langsung dan tidak langsung hanya membawa dampak ketidakefektifan alokasi belanja, khususnya pada pos belanja langsung. Pada belanja langsung, masih terdapat 3 alokasi, yaitu belanja pegawai, belanja barang dan jasa dan belanja modal. Meskipun belanja pegawai dan belanja barang dan jasa yang ada di pos ini bukanlah bagian belanja rutin, melainkan belanja program, namun nominalnya masih tercampur pada belanja langsung. Hal 
Vol.04, No.02, Oktober 2018

Doi: 10.24198/cosmogov.v2i2.xxxxx

ini menemukan bahwa demokratiasasi tidak berjalan secara paralel dengan akuntabilitas belanja publik. Sebab, pemimpin yang dipilih oleh rakyat belum tentu mampu menghasilkan kinerja yang lebih baik. Penyebab utamanya karena regulasi dari pemerintah pusat yang mengekang pemerintah daerah dalam mengelola keuangan sesuai kebutuhan rakyat di daerah. Ini menjadi tantangan besar bagi pemerintah daerah dalam menjalankan otoritasnya dalam mengelola keuangan daerah.

Berdasarkan dua kesimpulan yang telah dipaparkan di atas, maka menghasilkan pemimpin yang akuntabel tidak selalu berhubungan dengan bagaimana mereka dipilih, baik langsung oleh rakyat ataukah DPRD. Sebab, pilkada langsung terbukti tidak membawa dampak signifikan pada capaian kinerja pemerintahan yang lebih baik. Penyebab utamanya karena rezim regulasi desentralisasi yang belum sejalan dengan peraturan pengelolaan keuangan di daerah.

\section{DAFTAR PUSTAKA}

Abdullah, Sukriy dan Abdul Halim. (2009). Pengaruh Dana Alokasi Umum (DAU) dan Pendapatan Asli Daerah (PAD) terhadap Belanja Pemerintah Daerah Studi Kasus Kabupaten/Kota di Jawa dan Bali. Yogyakarta
Adib Irsyadi. (2004). Analisis FaktorFaktor Yang Mempengaruhi Alokasi Belanja Modal (Studi Empiris Pada Kabupaten/Kota di Provinsi Jawa Tengah. Universitas Muhammadiyah Surakarta Analisis Pengaruh Belanja Daerah Menurut Klasifikasi Fungsi Terhadap Pengentasan Kemiskinan di Era Desentralisasi Fiskal (Studi Kasus Pada Kabupaten/Kota di Pulau Jawa/Bali Tahun 20082010)

Artikel Suramadu Segera Rampung dalam http://kominfo.jatimprov.go.i $d /$ read/laporanutama/311http://tempo.co.id/ hg/nusa/jawamadura/2008/05 /22/brk,20080522-

123503.id.htmlhttp://www.an ggaran.depkeu.go.id/webcontentlist.asp? ContentId $=628$

Atragina, Kalapie. (2013). Analisis Faktor-Faktor Dibalik Prestasi Akuntabilitas Pemerintah Provinsi Jawa Timur, Universitas Negeri Surabaya Catatan Kinerja Jawa Timur Tahun 20092013 dalam http://prakarsajatim.com/catatan-kinerjapemerintah-provinsi-jawatimur-2009-2013/

Clemence Vergne. Democracy, Elections, and Allocation of 
Vol.04, No.02, Oktober 2018

Doi: $10.24198 /$ cosmogov.v2i2.xxxxx

Public Expenditure in

Developing Countries dalam Artikel

https://halshs.archives-

ouvertes.fr

Dana Bantuan Sosial Bukan Alat Bantu Politik dalam Warta Anggaran Edisi 28 Tahun 2014

Dede dan Caroline. (2008). Demokrasi dan Politik Desentralisasi. Yogyakarta : Graha Ilmu

Dinas Tenaga Kerja Transmigrasi dan Kependudukan Provinsi Jawa Timur dalam Laporan Akuntabilitas Kinerja Instansi Pemerintah (LAKIP) Tahun 2013

Faturochman, Demokrasi Lokal dalam Pemilihan Kepala Daerah Langsung di Indonesia dalam ejournal.umm.ac.idhttp://kan wil-

djpbjabar.net/index.php/keua ngan-publik/123-mengukurefisiensi-dan-efektivitasbelanja-dalam-reviupelaksanaan-anggaran

Fuad Aulia, Ihwan. Analisis Proses Penetapan Indikator Kinerja Pada Anggaran Berbasis Kinerja di Pemerintah Kota Malang. Universitas Brawijaya

Harian Tribun Timur, Kamis, 23 Maret 2007
I Gusti Agung Rai. (2008). Audit Kinerja Pada Sektor Publik. Jakarta: Salemba Empat

INOVASI, Volume 6, Nomor 2, Juni 2009 ISSN 1693-9034

Jimmy Ventius Parluhutan. (2016). Strategi Optimalisasi Penyerapan Anggaran Kota Bogor, dalam Jurnal Sekolah Pascasarjana Institut Pertanian Bogor.

Jurnal Akuntansi Sektor Publik Universitas Airlangga. Jurnal Konstitusi, Vol. III, No. 1, Juni 2010

Jurnal Pembangunan Daerah Edisi Juni 2015 Tahun VI

Kaho, Josef Riwu. (1991). Prospek

Otonomi Daerah di Negara Republik Indonesia. Yogyakarta: Fisipol Universitas Gajah Mada

Kusnandar, Dodik Siswantoro. (2010). Pengaruh Dana Alokasi Umum, Pendapatan Asli Daerah, Sisa Lebih Pembiayaan Anggaran dan Luas Wilayah terhadap Belanja Modal

Laporan Evaluasi Belanja Modal Daerah, Direktorat Jenderal Perimbangan Keuangan Kementerian Keuangan Republik Indonesia 2013

Laporan Pelaksanaan Spending Performance dalam Mendanai Pelayanan Publik. Kementerian Keuangan Republik Indonesia. 
Vol.04, No.02, Oktober 2018

Doi: 10.24198/cosmogov.v2i2.xxxxx

Direktorat Jenderal

Perimbangan Keuangan

Lestari, Sri dan Andi. (2010). Faktor-

Faktor

Penyebab

Rendahnya

Penyerapan

Belanja

Kementerian/Lembaga.

http://kemenkeu.go.id

Mardiasmo. (2004). Otonomi dan manajemen keuangan daerah. Yogyakarta :ANDI

Mungkasa, Oswar. (2015).

Desentralisasi dan Otonomi

Daerah di Indonesia:

Konsep, Pencapaian dan

Agenda Kedepan dalam

Muhammad Zaenuddin, Isu,

Problematika, dan

Dinamika Perekonomian

dan Kebijakan Publik,

Deepublish, Sleman 2015

Nasir, Mohammad. (1999). Metode

Penelitian. Jakarta :

Erlangga

Nawawi. (2012). Desentralisasi dan

Kinerja Pelayanan Publik.

Makassar: Penerbit CV

Menara Intan.

Pedoman Evaluasi Kinerja

Pembangunan Sektoral

dalam Kedeputian Evaluasi

Kinerja Pembangunan

Badan Perencanaan

Pembangunan Nasional

Tahun 2009

Pedoman Praktis Untuk Menganalisis

Pengeluaran Publik di

Tingkat Daerah, WorldBank

Pemerintah Siapkan Langkah-

Langkah Dorong
Percepatan Penyerapan

Anggaran dalam Artikel

Kementerian Republik

Indonesia di

http://www.kemenkeu.go.id/

Berita/pemerintah-siapkan-

langkah-langkah-dorong-

percepatan-penyerapan-

anggaran Diakses tanggal 8

November 2016

Prastowo, Andi. (2011). Metode

Penelitian Kualitatif dalam

Perspektif Rancangan

Penelitian. Yogyakarta: Arruzz Media

Profil Kemiskinan Provinsi Jawa

Timur 2012 dalam Badan

Pusat Statistik Jawa Timur

Putu Desak Intan, dkk. Pengaruh

Akuntabilitas, Kejelasan

Sasaran Anggaran dan

Partisipasi Anggaran

Terhadap Kinerja

Manajerial Satuan Kerja

Perangkat Daerah

Kabupaten Buleleng

Rasyid, Ryaas, dkk. (2002). Otonomi

Daerah dalam Negara

Kesatuan. Yogyakarta :

Pustaka Pelajar

Regional Dynamics in a

Decentralized Indonesia

dalam Jurnal College Asia

and The Pacific The

Australian National

University

Rusli Isa, Pemilihan Kepala Daerah

Langsung

Sebagai

Legitimasi Kepemimpinan

di Era Otonomi Daerah 
Vol.04, No.02, Oktober 2018

Doi: 10.24198/cosmogov.v2i2.xxxxx

Sadjiarto, Arja. (2000). Akuntabilitas dan Pengukuran Kinerja Pemerintahan. Jurnal Akuntansi dan Keuangan Vol. 2 November 2000: 138-150

Seri Analisis Pembangunan Wilayah Provinsi Jawa Timur Tahun 2013

Silalahi, Uber. (2009). Metode Penelitian Sosial. Bandung: Refika Aditama

Sudantoko, Djoko. (2003). Dilema Otonomi Daerah.

Yogyakarta : ANDI

Sutoro Eko, Pilkada Secara Langsung: Konteks, Proses dan Implikasi

The WorldBank, Electoral Accountability and Local Government Spending in Indonesia dalam Jurnal Poverty Reduction and Economic Management Network, Februari 2014

Utary, Anis Rachma. (2014). Audit Sektor Publik. Yogyakarta: Interpena

Wahyudi Kumorotomo, Akuntabilitas Anggaran Publik: Isu Politik, Prioritas Belanja, dan SILPA dalam Alokasi APBD di Beberapa Daerah 